\title{
RANCANG BANGUN PERANGKAT LUNAK PENGHITUNG KEBUTUHAN GIZI MASYARAKAT
}

\section{(DESIGNING NUTRITION NEED ANALYSIS COUNTER SOFTWARE)}

\author{
Titin Hera Widi Handayani, Deny Budi Hertanto, dan Ariadie Chandra Nugraha \\ Fakultas Teknik Universitas Negeri Yogyakarta \\ Jl. Colombo No.1 Yogyakarta \\ e-mail: titinhera_widi@yahoo.co.id
}

\begin{abstract}
Abstrak
Penelitian ini bertujuan untuk menghasilkan program aplikasi yang dirancang khusus untuk mengetahui masa tubuh, status gizi, dan nilai kebutuhan gizi dengan berpedoman kepada ilmu gizi dan kesehatan secara efisien, murah, dan akurat. Pembuatan sistem pada proses rancang bangun ini menggunakan metode rancang bangun software. Pada tahap pertama dilakukan analisis, yang terdiri dari analisis kebutuhan pemakai, analisis kerja, dan analisis teknologi. Tahap kedua adalah meliputi desain blok diagram, desain antarmuka, dan desain diagram alir program (flowchart). Tahap ketiga, menterjemahkan modul-modul hasil desain dengan menggunakan bahasa pemrograman ke dalam bentuk aplikasi atau biasa disebut coding/ implementation. Tahap keempat adalah pengujian sistem dengan menggunakan sistem pengujian black box testing. Rancangan aplikasi mencakup pembuatan struktur basis data, perancangan alur program, dan antarmuka pengguna. Rancangan basis data diwujudkan dalam 9 tabel. Alur program digambarkan dalam Diagram Entity Relationship, Diagram Alir Data, dan Diagram Alir Aplikasi. Rancangan antarmuka terdiri dari 17 tampilan/form aplikasi.
\end{abstract}

Kata kunci: perangkat lunak, kebutuhan gizi, ilmu gizi dan kesehatan

\begin{abstract}
This study was aimed at designing software that can calculate the nutritional needs of the community. The device is generated from an application program that is specifically designed to determine lean body mass, nutritional status and nutritional value needs. It is guided by the science of nutrition and health in an efficient, inexpensive and accurate ways. This study used design software method. The first stage of the analysis, which consists of user needs analysis, job analysis, and technology analysis. The second stage is a block diagram including interface design and flowchart design. The third stage, design modules translation was done using a programming language into the application form called coding/ implementation. The fourth stage was testing the system using black box testing. The application design includes the creation of database structure, program flow design and user interface. The design of the database was realized in 9 tables. The flow program was depicted in Entity Relationship Diagram, Data Flowchart and Applications Flowchart. The interface design consisted of 17 display interfacel application form.
\end{abstract}

Keywords: software, nutritional needs, science of nutrition and health 


\section{PENDAHULUAN}

Manusia memerlukan sejumlah zat gizi untuk dapat hidup sehat dan mempertahankan kesehatan. Jumlah zat gizi yang diperoleh melalui konsumsi pangan haruslah mencukupi kebutuhan tubuh. Hal ini diperlukan untuk melakukan berbagai kegiatan, pemeliharaan tubuh dan pertumbuhan bagi yang masih dalam masa pertumbuhan.

Zat gizi diperoleh dari konsumsi pangan merupakan kebutuhan energi manusia yang tidak boleh mengalami kekurangan ataupun kelebihan. Jika kekurangan ataupun kelebihan terjadi dalam jangka waktu yang lama maka dapat membahayakan kesehatan. Zat-zat gizi bekerja secara bersama yang akan berperan menghasilkan energi, membangun dan mengganti jaringan tubuh, serta mengatur berbagai proses dalam tubuh. Kekurangan ataupun kelebihan salah satu zat gizi akan menggangu proses yang terjadi di dalam tubuh dan dapat mengakibatkan timbulnya penyakit. Berbagai zat gizi yang diperlukan tubuh dapat digolongkan ke dalam enam macam, yaitu karbohidrat, lemak, protein, vitamin, mineral, dan air.

Beberapa persoalan terkait kekurangan zat gizi atau status gizi yang rendah telah melanda masyarakat di berbagai daerah di Indonesia. Sujai, Adiyanti, \& Huriyati (2013) menyatakan bahwa ketahanan pangan yang rendah menyebabkan status gizi yang rendah. Sedangkan status gizi yang rendah pada anak-anak SD menyebabkan prestasi belajar menurun. Palupi, Hadi, dan Soenarto (2009) menyatakan bahwa asupan gizi yang rendah menyebabkan diare akut pada anakanak. Pampang, Purba, \& Huriyati (2009) juga menyatakan bahwa asupan gizi yang tinggi namun aktivitas fisik yang rendah menyebabkan terjadinya obesitas pada anakanak SMP.

Tenaga kerja dalam tataran pembangunan nasional dan daerah memiliki bahkan dikatakan identik dengan sumber daya manusia (human resource) yang merupakan hal penting dalam penyelenggaraan pembangunan nasional. Tanpa tenaga kerja, pembangunan tidak dapat terlaksana dengan baik. Demikian pula, jika tenaga kerja yang ada berkualitas rendah baik secara fisik, mental maupun sosial. Rendahnya produktivitas kerja dianggap akibat kurangnya motivasi kerja, tanpa menyadari faktor lainnya seperti gizi pekerja. Perbaikan dan peningkatan gizi mempunyai makna yang sangat penting dalam upaya mencegah morbiditas atau keadaan sakit, menurunkan angka absensi serta meningkatkan produktivitas kerja. Berat ringannya beban kerja seseorang ditentukan oleh lamanya waktu melakukan pekerjaan dan jenis pekerjaan itu sendiri. Semakin berat beban kerja, sebaiknya semakin pendek waktu kerjanya agar terhindar dari kelelahan dan gangguan fisiologis yang berarti atau sebaliknya. 
Kebutuhan gizi (requirement) adalah jumlah zat gizi minimal yang diperlukan seseorang untuk hidup sehat. Kebutuhan zat gizi masing-masing orang berbeda, salah satunya karena faktor genetika. Kegunaan perhitungan kebutuhan gizi adalah sebagai baku evaluasi konsumsi pangan dan gizi, perencanaan menu atau konsumsi pangan dan ketersediaan pangan. Kecukupan gizi yang dianjurkan (recommended dietary allowances/RDA) adalah jumlah zat gizi yang diperlukan seseorang atau rata-rata kelompok orang agar hampir semua orang dapat hidup sehat.

Kebutuhan gizi seseorang sangat dipengaruhi oleh faktor pertumbuhan, usia, jenis kegiatan fisik, dan ukuran tubuh, serta keadaan fisiologis khusus. Metode analisis gizi yang dapat digunakan yaitu metode basal dan metode faktorial.

Langkah metode basal dan faktorial yaitu: (1) mencari nilai Indeks Masa Tubuh (IMT), (2) mencari nilai Basal Metabolisme Rate (BMR), (3) mencari energi tambahan berdasarkan tingkat aktivitas, (4) mencari nilai Specific Dynamic Action (SDA), (5) mencari energi tambahan berdasarkan keadaan fisiologis khusus, (6) mencari energi tambahan berdasarkan tingkat pertumbuhan, dan (7) menghitung total energi.

Berikut disajikan adalah langkahlangkah Metode Analisis Gizi secara rinci.

Langkah pertama adalah mencari nilai Indeks Masa Tubuh (IMT) dengan rumus:

$I M T=\frac{B B}{(T B)^{*}(T B)}$

\section{Keterangan:}

IMT : Indeks Masa Tubuh

BB : Berat Badan (Kg)

TB : Tinggi Badan (m)

Langkah kedua, mencari nilai BMR. Nilai BMR laki-laki dan perempuan berbeda. Rumus BMR laki-laki disajikan pada Persamaan (2) dan BMR perempuan disajikan pada Persamaan (3).

$$
\begin{aligned}
& B M R=66,47-(6,76 * U)+(13,75 * B B)+(5 * T B)(2) \\
& B M R=665,2-(4,77 * U)+(9,56 * B B)+(1,7 * T B)(3)
\end{aligned}
$$

\section{Keterangan:}

BMR : Basal Metabolisme Rate (Kalori)

Tabel 1

\begin{tabular}{cll}
\multicolumn{2}{l}{ Indeks Masa Tubuh } \\
\hline No & \multicolumn{1}{c}{ Nilai IMT } & \multicolumn{1}{c}{ Status } \\
\hline 1 & $(<17)$ & Kekurangan berat badan tingkat berat \\
2 & $(>=17)$ dan $(<18,5)$ & Kekurangan berat badan tingkat ringan \\
3 & $(>=18,5)$ dan $(<=25)$ & Keadaan tubuh normal \\
4 & $(>25)$ dan $(<=27)$ & Kelebihan berat badan tingkat ringan \\
5 & $(>27)$ & Kelebihan berat badan tingkat berat \\
\hline
\end{tabular}


BB : Berat Badan $(\mathrm{Kg})$

U : Usia (Tahun)

TB : Tinggi Badan $(\mathrm{cm})$

Langkah ketiga, mencari energi tambahan berdasarkan tingkat aktivitas dengan rumus:

\section{Energi Tambahan Aktivitas=Koefisien Aktivitas*} $B M R$

Koefisien aktivitas metode basal dan faktorial disajikan pada Tabel 2.

Tabel 2

Koefisien Aktivitas

\begin{tabular}{llc}
\hline No & Tingkat Aktivitas & Koefisien \\
\hline 1 & Ringan & 0,5 \\
2 & Sedang & 0,7 \\
3 & Berat & 1 \\
\hline
\end{tabular}

Langkah keempat, mencari nilai SDA dengan rumus:

SDA $=10 \%(B M R+$ Energi Tambahan Aktivitas $)$

Langkah kelima, mencari energi tambahan berdasarkan keadaan fisiologis khusus. Energi tambahan ini bersifat kondisional. Tambahan energi untuk keadaan fisiologis kehamilan memiliki kebutuhan khusus seperti halnya tambahan energi untuk keadaan fisiologis menyusui.

Langkah keenam, mencari energi tambahan berdasarkan tingkat pertumbuhan dengan rumus:

Energi Tambahan Pertumbuhan=Koefisien * Berat Badan

Langkah ketujuh, menghitung Total Energi dengan rumus:

Total Energi $($ Kalori $)=B M R+S D A+$ Energi Tambahan Aktivitas +Energi Tambahan Pertumbuhan+Energi Tambahan Fisiologis

Suwarni, Asdie, dan Astuti (2009) menyatakan bahwa adanya konseling gizi akan meningkatkan status gizi masyarakat. Dengan latar belakang serta pertimbangan tersebut maka dirancang suatu perangkat lunak yang dapat digunakan dengan mudah untuk mengetahui informasi seputar angka kebutuhan gizi dan status gizi. Tujuan dari perancangan perangkat lunak ini adalah untuk membuat sebuah perangkat lunak yang dapat mengetahui angka kebutuhan gizi dan status gizi dengan berpedoman kepada ilmu

Tabel 3

Koefisien Pertumbuhan Metode Basal

\begin{tabular}{cclc}
\hline No & Usia & \multicolumn{1}{c}{ Status } & Koefisien \\
\hline 1 & $(<=10)$ dan $(<15)$ & Pertumbuhan awal & 2 \\
2 & $(>=15)$ dan $(<16)$ & Pertumbuhan menengah & 1 \\
3 & $(>=16)$ dan $(<18)$ & Pertumbuhan akhir & 0,5 \\
\hline
\end{tabular}


gizi dan kesehatan secara efisien, murah dan akurat.

\section{METODE}

Langkah-langkah rancang bangun yang digunakan mengacu pada Pressman (2012). Secara garis besar langkah-langkahnya terdiri atas: (1) deskripsi dan analisis kebutuhan, (2) perancangan, (3) pembuatan atau implementasi, (4) pengujian dan validasi, (5) perbaikan, (6) perapian, (7) uji coba pemakaian atau implementasi, (8) revisi, dan (9) finishing.

Tahap pertama perancangan adalah membuat analisis kebutuhan sistem. Hasilnya berupa daftar kebutuhan antara lain teori-teori ilmu gizi, Angka Kecukupan Gizi (AKG) Indonesia, dan komposisi bahan makanan. Perangkat komputer yang sesuai, bahasa dan alat pemograman, serta konsultan gizi juga dibutuhkan. Tahap berikutnya adalah merancang sistem. Untuk mengembangkan aplikasi, rancangan basis data, rancangan antarmuka dan alur pemrograman harus dibuat sebaik mungkin. Langkah-langkah dalam penelitian di antaranya adalah seperti berikut ini.

Pertama, analisis kebutuhan sistem. Software penghitung kebutuhan gizi berbasis Borland Delphi 7 ini diharapkan mampu menjadi alternatif pilihan masyarakat dalam upaya peningkatan kesehatan masyarakat yang mengacu pada sistem kepakaran berbasis teknologi komputerisasi. Software ini dirancang untuk dapat melakukan operasi aritmatika yang telah dimasukan user dan menampilkan data yang telah dimasukkan oleh pemrogram ke database.

Pembuatan software penghitung kebutuhan gizi berbasis Borland Delphi 7 ini membutuhkan beberapa komponen yang dibutuhkan. Komponen yang dibutuhkan tersebutmeliputi:(1)perangkatlunakBorland Delphi 7.0 yang digunakan untuk mendesain tampilan dan sekaligus memprogramnya dengan bahasa pascal, (2) perangkat lunak MySQL yang digunakan untuk membuat database, (3) PDF Viewer sebagai perangkat lunak untuk dapat menampilkan format PDF di Borland Delphi 7, (4) HelpNDoc sebagai perangkat lunak untuk mendesain file help, (5) perangkat lunak PDF yang digunakan untuk membaca file berformat pdf, (6) perangkat komputer yang digunakan adalah prosesor intel core 2 duo centrino $2.20 \mathrm{GHz}$, hardisk $320 \mathrm{~GB}$, keyboard, mouse, (7) MySQL connector ODBC 3.51 sebagai penghubung database MySQL dengan Borland Delphi 7, (8) referensi yang berkaitan dengan perangkat lunak, database, pemrograman Borland Delphi 7 dan mysql, dan (9) informasi-informasi yang berkaitan dengan software penghitung kebutuhan gizi berbasis Borland Delphi 7. Informasi tersebut meliputi: teori-teori ilmu gizi, AKG Indonesia, dan komposisi bahan makanan. 
Kedua, perancangan sistem. Pada tahap ini dilakukan perancangan antarmuka, perancangan basis data, perancangan Diagram Alir Data (DAD) dan flowchart program. Perancangan basis data diawali dengan menulis kamus data yang akan digunakan, kemudian menyusun tabel-tabel data, setelah itu menyusun Entity Relationship Diagram yang menggambarkan hubungan antartabel dalam basis data. Setelah basis data jadi, barulah menyusun DAD, flowchart, dan antarmuka yang akan digunakan.

Ketiga, implementasi program. Pada tahap ini, rancangan basis data dibuat ke dalam MySQL 4.0, rancangan antarmuka dibuat di Delphi, kemudian menuliskan kode-kode program sesuai dengan DAD, ERD, dan flowchart program. Setiap rancangan dirangkai menjadi satu kesatuan sistem yang saling terkait satu sama lain.

Langkah berikutnya adalah melakukan pemasangan ke sistem windows untuk menjalankan program versi prototype. Langkah terakhir adalah pengaturan konten agar rapi sesuai kategori dan agar mempermudah pengguna dalam mencari konten yang diinginkan.

Keempat, pengujian terhadap aplikasi penghitung gizi. Pengujian terhadap produk aplikasi penghitung nilai gizi dilakukan dengan dua cara, yaitu black box testing dan validasi oleh para ahli. Kedua pengujian tersebut akan menunjukkan unjuk kerja atau kinerja dari aplikasi. Pengujian black box testing dimaksudkan untuk menguji sistem dapat berfungsi sebagaimana fungsi yang direncanakan atau tidak. Validasi yang dilakukan oleh ahli materi dan ahli media. Validasi dimaksudkan untuk mengetahui aplikasi penghitung gizi layak digunakan atau tidak.

Kelima, perbaikan terhadap produk aplikasi penghitung gizi. Jika unjuk kerja produk aplikasi penghitung gizi masih diperoleh hasil yang kurang sesuai dengan harapan, misalnya hasil black box testing masih menunjukkan adanya bagian yang belum berfungsi sebagaimana fungsinya atau hasil validasi ahli materi atau ahli media masih menunjukkan hal kurang sesuai dengan harapan maka perlu dilakukan perbaikan terhadap produk aplikasi penghitung gizi tersebut. Jika hasil perbaikan terhadap produk tersebut telah selesai maka perlu dilakukan pengujian lagi dengan prosedur seperti tersebut di atas.

Keenam, perapihan. Apabila hasil pengujian black box testing dan validasi ahli materi dan ahli media telah menunjukkan hasil unjuk kerja aplikasi penghitung gizi baik, maka langkah berikutnya adalah merapikan produk tersebut, seperti merapikan tampilan/antarmuka, merapikan gambar, dan sebagainya. 


\section{HASIL DAN PEMBAHASAN}

Hasil dari rancangan dijelaskan dalam uraian berikut ini. Analisis kebutuhan sistem adalah (1) perangkat lunak Borland Delphi 7.0 yang digunakan untuk mendesain tampilan dan sekaligus memprogramnya dengan bahasa pascal, (2) perangkat lunak MySQL yang digunakan untuk membuat database, (3) PDF Viewer sebagai perangkat lunak untuk dapat menampilkan format PDF di Borland Delphi 7, (4) HelpNDoc sebagai perangkat lunak untuk mendesain file help, (5) perangkat lunak PDF yang digunakan untuk membaca file berformat pdf, (6) perangkat komputer yang digunakan: prosesor intel core 2 duo centrino $2.20 \mathrm{GHz}$, hardisk $320 \mathrm{~GB}$, keyboard, mouse, (7) MySQL connector ODBC 3.51 sebagai penghubung database MySQL dengan Borland Delphi 7, dan (8) referensi yang berkaitan dengan perangkat lunak, basis data, dan pemrograman Borland Delphi 7 dan mysql.

Rancangan sistem meliputi basis data, alur program, diagram relasi basis data, danrancangantampilan. Basis data yang dirancang terdiri dari sembilan tabel yang dihasilkan dari kamus data, yaitu: tabel durt, tabel energi aktivitas, tabel komposisi bahan makanan, tabel kategori, tabel usia, tabel gizi, tabel status, tabel bacaan, dan tabel aktivitas pengguna.

Tabel durt berisi informasi tentang bahan makanan beserta ukuran dalam rumah tangga. Tabel energi aktivitas berisi informasi tentang macam-macam aktivitas dan jumlah energi yang dibutuhkan untuk aktivitas tertentu. Tabel komposisi bahan makanan berisi informasi tentang macammacam bahan makanan beserta kandungan gizi dalam makanan tersebut. Tabel gizi berisi tentang kebutuhan-kebutuhan gizi manusia. Tabel kategori berisi informasi tentang kategori dari user. Tabel usia berisi informasi tentang kelompok usia dari user. Tabel status berisi informasi tentang data akun dan password. Tabel bacaan berisi informasi tentang data-data judul teori gizi. Tabel aktivitas pengguna berisi informasi tentang aktivitas yang dilakukan.

Pada tabel durt terdapat 4 buah field dengan field nomor sebagai primary key. Tabel energi aktivitas terdapat 3 buah field dengan field nomor sebagai primary key. Tabel komposisi bahan makanan terdapat 13 field dengan field nomor sebagai primary key. Tabel kategori terdapat 2 buah field dengan field nomor sebagai primary key. Tabel usia terdapat 2 buah field dengan field nomor sebagai primary key. Tabel gizi terdapat 27 field dengan field kategori dan kelompok mempunyai fungsi sebagai foreign key. Tabel status terdapat 3 buah field dengan field nomor sebagai primary key. Tabel bacaan terdapat 3 buah field dengan field nomor sebagai primary key. Tabel aktivitas pengguna terdapat 5 buah field dengan field nomor sebagai primary key. 
Proses dasar dari sistem ini dapat dilihat secara garis besar dari Data Flow Diagram (DFD) yang dirancang, terdiri dari DFD mulai level 0 sampai dengan level 3. Berikut ini contoh DFD Level 0. Dalam DFD level 0 dapat dilihat bahwa ada dua entitas luar (external entity) yaitu Publik dan Admin. Rancangan DFD disajikan pada Gambar 1.

Pada rancangan Diagram Relasi basis data, ada tiga tabel yang saling berelasi antara tabel satu dengan tabel yang lainnya yaitu tabel gizi, tabel kategori, dan tabel usia. Relasi yang ada adalah hubungan atau relasi antarentri data pada tiap-tiap tabel. Pada setiap tabel data akan diwakili dengan sebuah field yang dijadikan field indeks untuk merelasikan dengan tabel yang lain.
Tabel gizi dan tabel kategori direlasikan melalui field kategori yang berada pada masing-masing tabel. Tabel gizi dan tabel usia direlasikan melalui field kelompok yang berada pada masing-masing tabel. Relasi antartabel disajikan pada Gambar 2. Gambar 3 menyajikan hubungan data tabel.

Pada rancangan tampilan, ditunjukkan tiga contoh rancangan form, yaitu tampilan form beranda (Home) (Gambar 4), tampilan form menu utama (Gambar 5), dan tampilan form analisis gizi (Gambar 6). Menu login meliputi tombol masuk, tombol keluar, gambar latar belakang, dan status bar. Form menu utama terdiri dari menu utama, menu analisis, menu fitur, menu manajemen data, manajemen akun, kotak keterangan, status

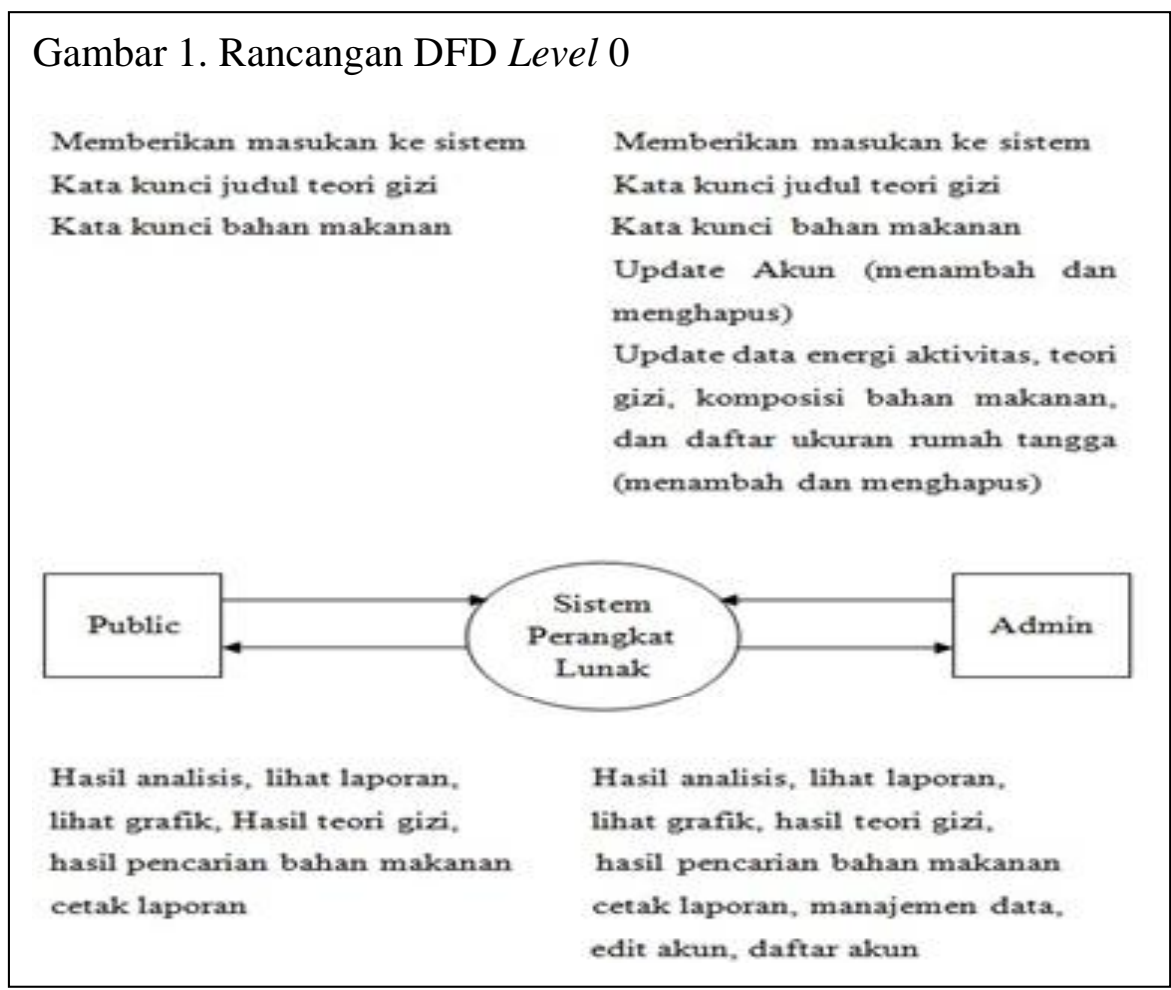


Gambar 2. Hubungan Relasi Antartabel

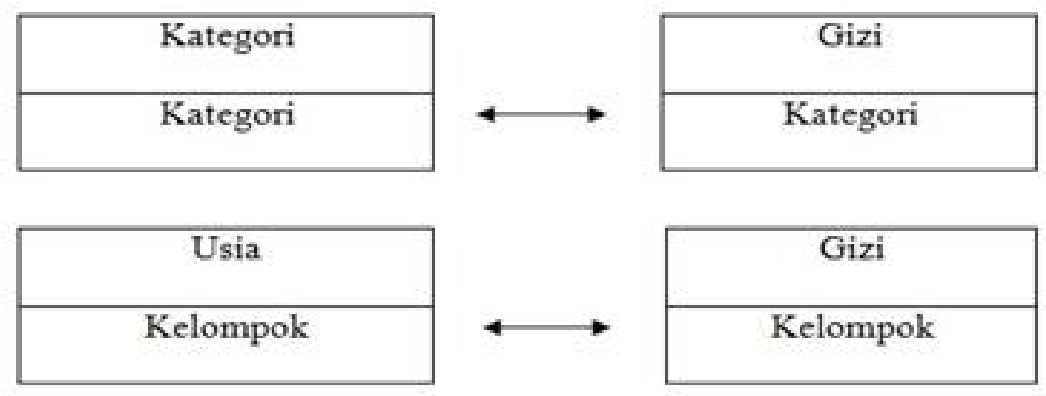

Gambar 3.Gambaran Hubungan Data Tabel

Tabel Gizi

\begin{tabular}{|c|c|c|c|}
\hline Kategori & Tinggi_badan & Berat_badan & Kelompok \\
\hline Balita & 71 & 8.5 & 1 \\
\hline
\end{tabular}

Tabel Kategori

\begin{tabular}{|c|c|}
\hline Nomor & Kategori \\
\hline 1 & Balita \\
\hline
\end{tabular}

Tabel Usia

\begin{tabular}{|c|c|}
\hline Nomor & Kelompok \\
\hline 1 & 1 \\
\hline
\end{tabular}

Gambar 4. Rancangan Form Beranda

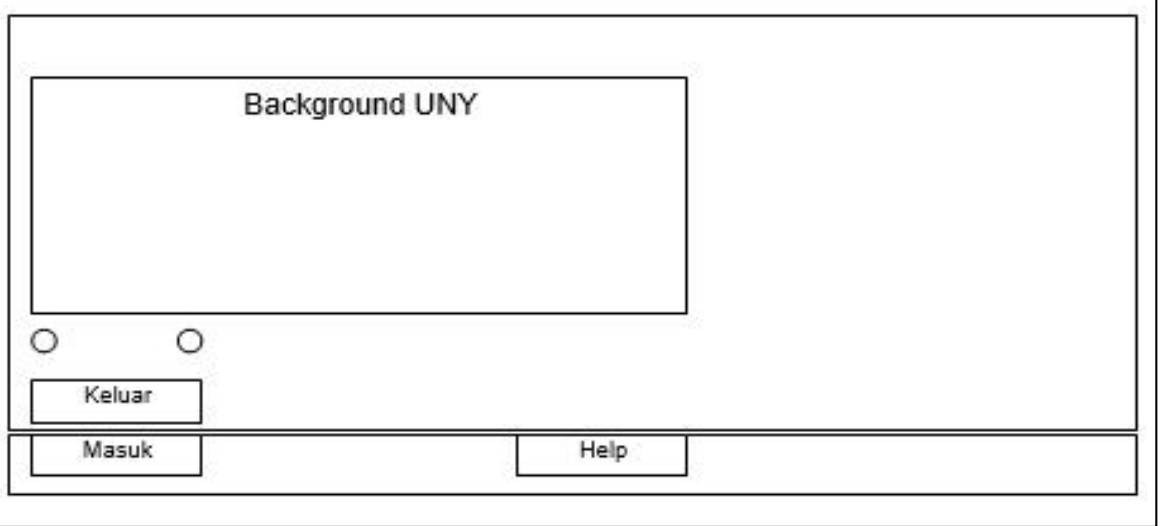


Jurnal Penelitian Saintek, Vol. 21, Nomor 2, Oktober 2016

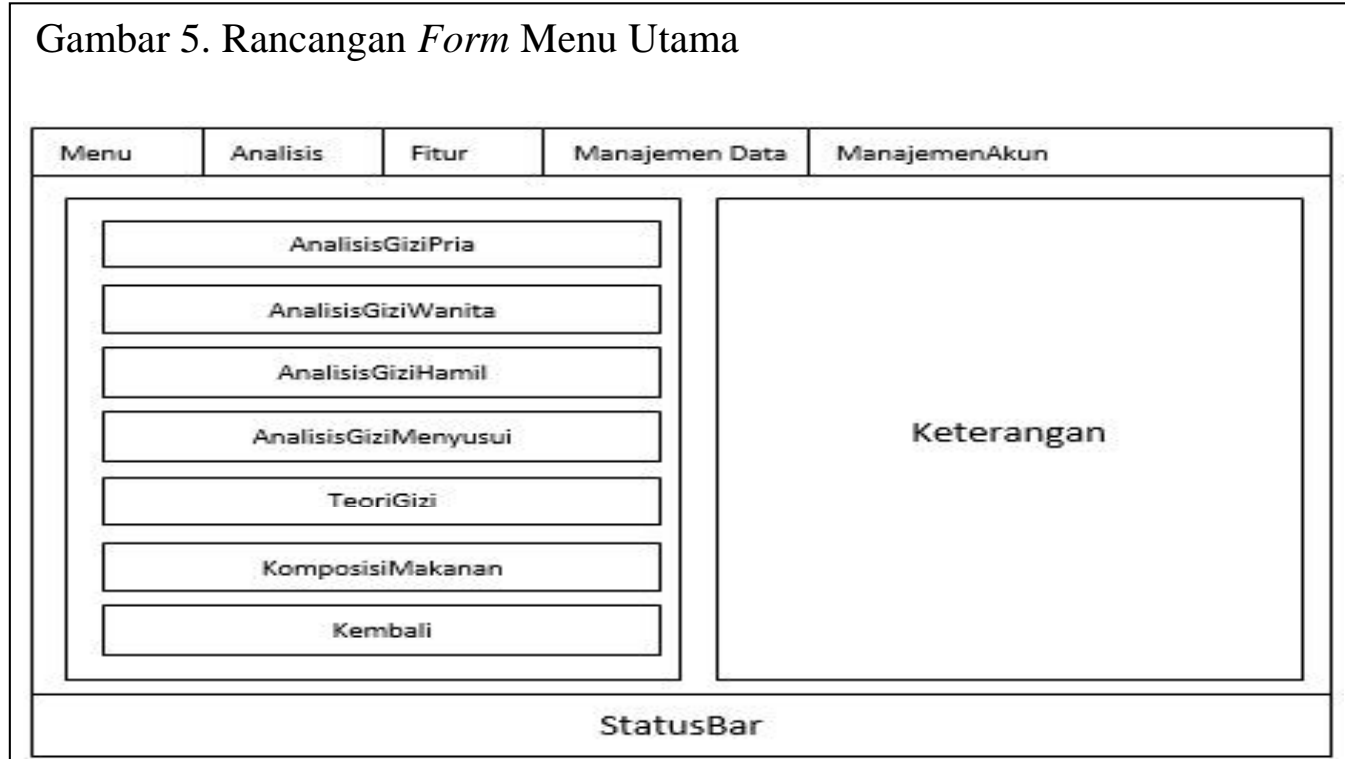

\section{Gambar 6. Rancangan Form Analisis Gizi}

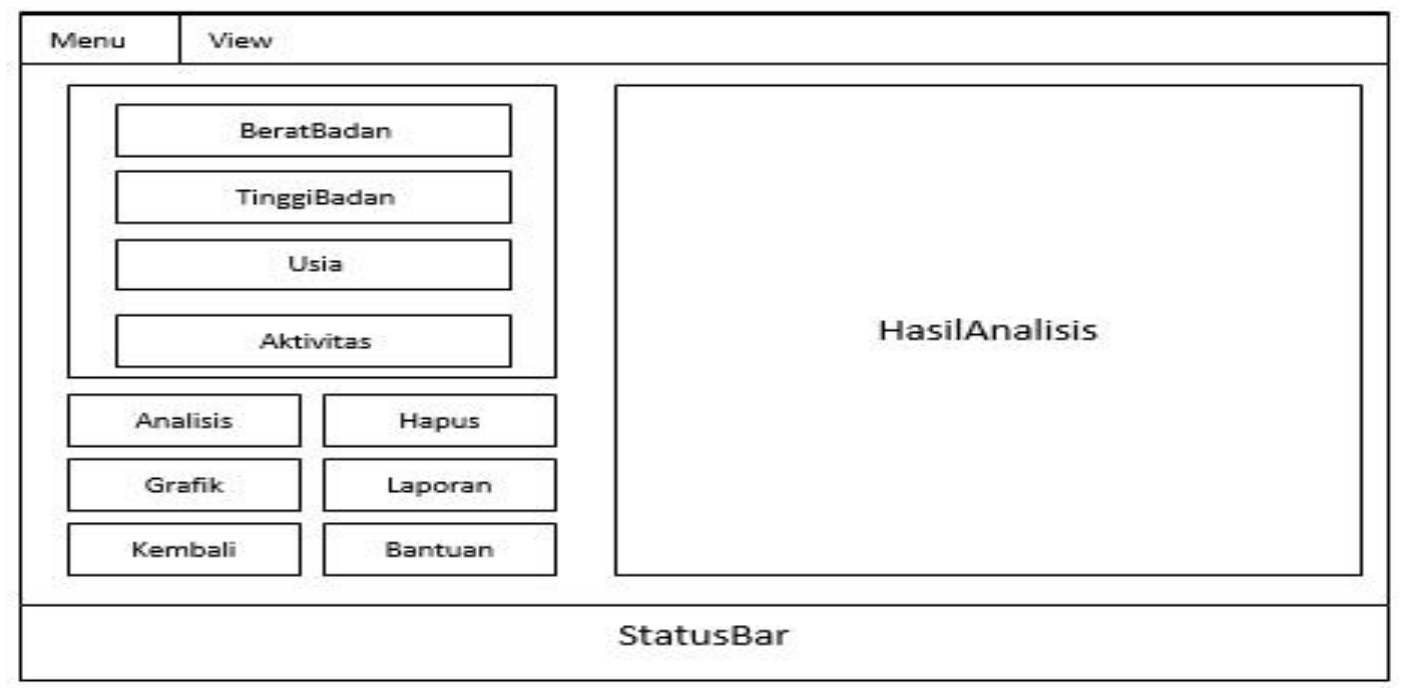

bar dan tombol-tombol yang terkait analisis gizi. Form analisis gizi adalah form di mana pengguna akan memasukkan berbegai data yang dibutuhkan untuk menganalisis kebutuhan gizi, seperti data berat badan, tinggi badan, dan data lainnya.

Form Beranda merupakan bagian tampilan yang digunakan untuk menentukan 
kategori pengguna yang memanfaatkan atau menjalankan program sistem informasi. Pada form pembukaan ini terdapat dua pilihan kategori pengguna, yaitu admin dan publik. Pengguna yang memillih sebagai kategori admin maka harus menekan tombol administrator kemudian akan muncul form memerintahkan untuk memasukkan user login dan password sebelum masuk pada form utama. Admin mempunyai hak akses penuh, yaitu dapat menampilkan, menambah, mengubah dan menghapus data yang disajikan. Sedangkan kategori sebagai publik, pengguna dapat langsung melakukan login.

Langkah berikutnya adalah implementasi program. Tampilan implementasi program disajikan pada Gambar 7. Pada tahap ini, rancangan basis data dibuat ke dalam MySQL 4.0, rancangan antarmuka dibuat di Delphi, kemudian menuliskan kode-kode program sesuai dengan DAD, ERD, dan diagram alir program. Setiap rancangan dirangkai menjadi satu kesatuan

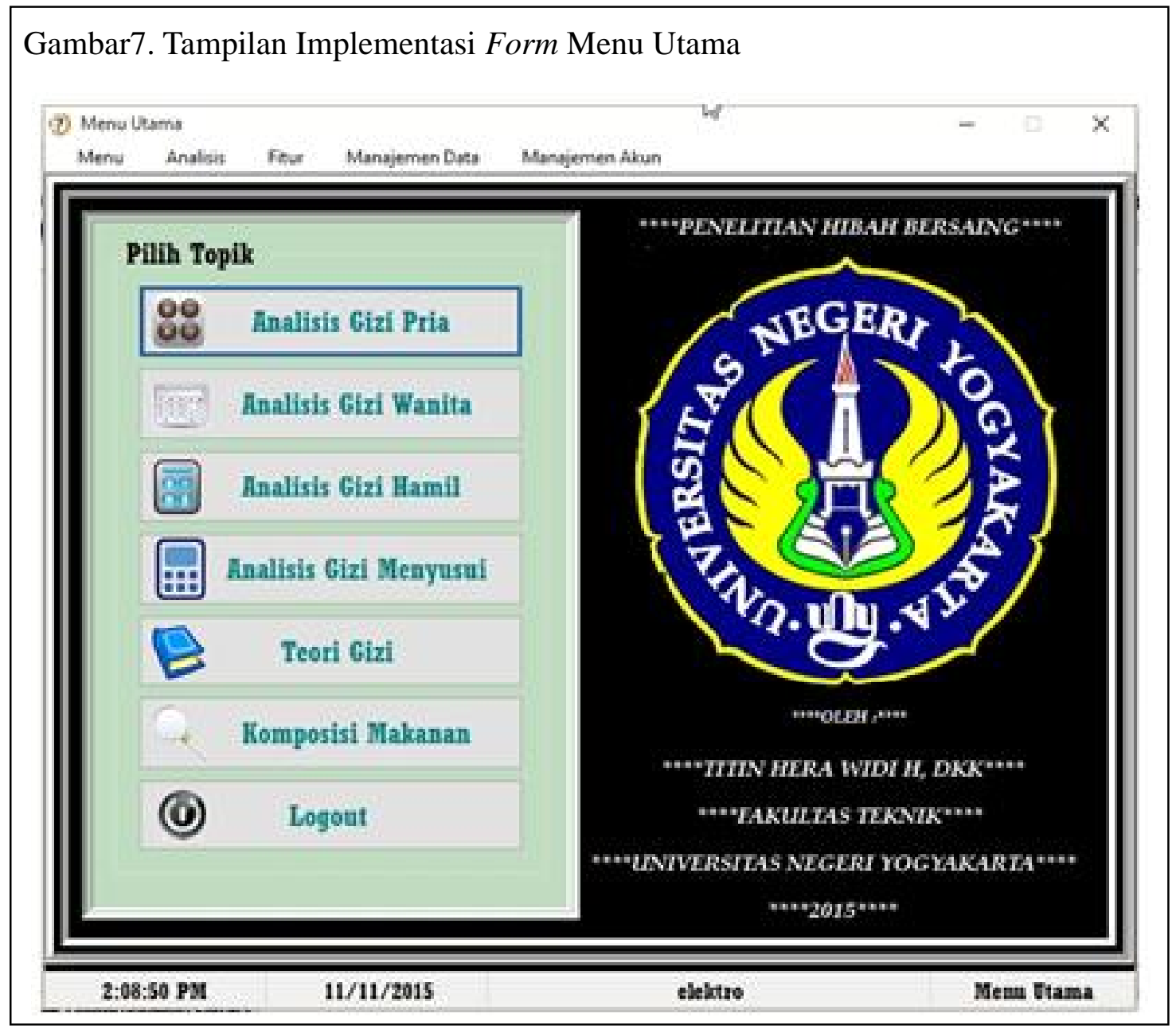


sistem yang saling terkait satu sama lain. Langkah berikutnya adalah melakukan pemasangan ke sistem operasi Windows untuk menjalankan program versi prototype. Langkah terakhir adalah pengaturan konten agar rapi sesuai kategori dan agar mempermudah pengguna dalam mencari konten yang diinginkan. Berikut contoh tampilan implementasi perancangan aplikasi penghitung gizi.

Rata-rata hasil pengujian secara keseluruhan dapat dilihat pada Tabel 6 .

Tabel 6

Rata-rata Hasil Pengujian Keseluruhan

\begin{tabular}{lcc}
\hline Analisis Gizi & $\begin{array}{c}\text { Respon } \\
\text { Sistem } \\
\text { (detik) }\end{array}$ & $\begin{array}{c}\text { Ketepatan } \\
(\%)\end{array}$ \\
\hline Metode Basal & 0,88 & 100 \\
Metode Faktorial & 1,09 & 100 \\
\hline Rata-rata & 0,985 & 100 \\
\hline
\end{tabular}

Tahap pengujian selanjutnya adalah uji kelayakan oleh dua orang ahli media. Ahli media 1 menghasilkan nilai 3,69; sementara ahli media media kedua menghasilkan nilai 3,31. Rata-rata uji kelayakan dari dua ahli adalah 3,5. Berdasarkan nilai rata-rata tersebut, dapat dinyatakan bahwa aplikasi gizi layak untuk diterapkan.

\section{SIMPULAN}

Rancangan aplikasi mencakup pembuatan struktur basis data, perancangan alur program dan antarmuka pengguna. Rancangan basis data diwujudkan dalam 9 tabel. Alur program digambarkan dalam Diagram Entity Relationship, Diagram Alir Data, dan Diagram Alir Aplikasi. Rancangan antarmuka terdiri dari 17 tampilan/ form aplikasi. Selanjutnya implementasi dari proses desain ini diharapkan akan menghasilkan suatu perangkat lunak yang dapat digunakan untuk mengetahui masa tubuh, status gizi dan nilai kebutuhan gizi yang dapat digunakan dengan mudah dalam kehidupan sehari-hari sehingga pada akhirnya dapat meningkatkan kualitas gizi masyarakat.

\section{DAFTAR PUSTAKA}

Palupi, A., Hadi, H., \& Soenarto, S. S. (2009). Status gizi dan hubungannya dengan kejadian diare pada anak diare akut di ruang rawat inap RSUP Dr. Sardjito Yogyakarta. Jurnal Gizi Klinik Indonesia, 6(1), 1-7.

Pampang, E., Purba, M. B., \& Huriyati, E. (2009). Asupan energi, aktivitas fisik, persepsi orang tua, dan obesitas siswa dan siswi SMP di Kota Yogyakarta. Jurnal Gizi Klinik Indonesia (The Indonesian Journal of Clinical Nutrition), 5(3), 108-113.

Pressman, R. S. (2002). Rekayasa perangkat lunak. Yogyakarta: Andi Offset.

Sujai, A., Adiyanti, M. G., \& Huriyati, E. (2013). Ketahanan pangan rumah 
tangga, status gizi, dan prestasi belajar siswa sekolah dasar. Jurnal Gizi Klinik Indonesia, 9(3), 104-110.

Suwarni, Asdie, A. H., \& Astuti, H. (2009). Konseling gizi dan pengaruhnya terhadap asupan zat gizi dan tekanan darah pada pasien hipertensi rawat jalan di Rumah Sakit Umum Daerah Provinsi Sulawesi Tenggara. Jurnal Gizi Klinik Indonesia, 6(1), 21-28. 